\title{
ANALYSIS OF ORGANIC CHEMISTRY TASKS IN TEXTBOOKS FOR SECONDARY SCHOOLS
}

\section{[ANALYZA ULOH Z ORGANICKEJ CHEMIE V UCEBNICIACH PRE STREDNE SKOLY]}

\author{
Simona Stefankova - Jana Branisa - Zita Jenisova
}

doi: 10.18355/PG.2018.7.1.2

\begin{abstract}
Representing learning tasks of different cognitive difficulty in textbooks greatly affects the level of acquired education. Through the learning task, we verify, or the students actually understand the lesson. It is clear that the tasks in the textbooks serve to develop students' thinking and stimulate their activity. This paper focuses on the analysis of teaching tasks in two textbooks of chemistry for the 2nd grammar school. Learning assignments are analyzed according to quantity, a form of assignment, content orientation and cognitive difficulty according to the original Bloom taxonomy. The analysis of textbooks has shown less representation of the learning tasks of the higher cognitive difficulty of the solution and the lack of non-verbal tasks.
\end{abstract}

\section{Key words}

textbooks, learning tasks, cognitive skills, organic chemistry, Bloom taxonomy

\section{Anotácia}

Zastúpenie učebných úloh rôznej kognitívnej náročnosti $\mathrm{v}$ učebniciach do značnej miery ovplyvňuje úroveň získaného vzdelania. Prostredníctvom učebnej úlohy overujeme či študenti skutočne danému učivu porozumeli. Je zrejmé, že úlohy uvedené v učebniciach slúžia na to, aby rozvíjali myslenie študentov a podnecovali ich aktivitu. Tento príspevok sa zameriava na analýzu učebných úloh v dvoch učebniciach chémie pre 2. ročník gymnázia. Učebné úlohy sú analyzované podl'a kvantity, formy zadania, obsahového zamerania a z hl'adiska kognitívnej náročnosti podl'a pôvodnej Bloomovej taxonómie. Analýza učebníc poukázala na menšie zastúpenie učebných úloh vyššej kognitívnej náročnosti riešenia a na nedostatok neverbálne zadaných úloh.

\section{Kl’účové slová}

učebnice, učebné úlohy, kognitívne zručnosti, organická chémia, Bloomova taxonómia

\section{Úvod}

Organická chémia sa všeobecne považuje za náročnú oblast' chemického vzdelávania. V protiklade so stredoeurópskou tradíciou sa jej vyučovanie väčšinou zavádza až na sekundárnom stupni, kde sa predpokladá vyššia intelektová a vedomostná úroveň študentov, ktorá je daná vyšším vekom, 
dížkou vzdelávania, ale aj selekciou populácie so zámerom d’alšieho štúdia. $\mathrm{K}$ výučbe chémie neodmyslitel'ne patria i príslušné učebnice a učebné úlohy, ktoré sú sprievodcom $\mathrm{k}$ rozvoju teoretického i praktického poznania študentov. Štúdia TIMSS 2007 (Martin et al., 2008) preukázala, že na každej vyučovacej hodine v priemere $40 \%$ celkového času pracujú učitelia a študenti $\mathrm{s}$ učebnicou. $\mathrm{V}$ procese vzdelávania slúžia učebnice študentom na ul'ahčenie porozumenia subjektom, javom a vedeckej teórii (Athineva, 2005). Spomenuté opisy subjektov alebo javov sú zvyčajne vyberané tak, aby zodpovedali utváraniu vizuálnych vnemov $u$ študentov. Učebnica sa preto používa ako hlavný nástroj na ilustráciu. Obsah poznatkov a spôsob ich prezentácie sú kl'účom pre hodnotenie kvality individuálneho učenia (Liu, 2016). Pedagógovia sa jednomysel'ne zhodujú, že učebnice fungujú ako hlavný zdroj informácií pre výučbu prírodovedných predmetov a ich kvalita a obsah sú rozhodujúcim kritériom efektívneho vzdelávania. Podl’a Tomlisona (2001) sa jedná o „najpohodlnejší spôsob prezentovania učiva“, ktorý prispieva $\mathrm{k}$ súdržnosti vyučovania. Učebnica taktiež poskytuje študentom pocit systematickosti, celistvosti a postupného pokroku a pomáha učitel'ovi pri príprave a študentom pri opakovaní si. Garinger (2001) zastáva názor, že používanie učebnice je efektívna a l’ahko dostupná cesta, ktorá zmierňuje nátlak na učitel'a, skracuje čas domácej prípravy a poskytuje pripravené úlohy pre študentov. Učebnice môžu určovat' smer, obsah vyučovania alebo tiež spôsob ako by mohla daná vyučovacia hodina prebiehat'. McGrath (2002) konštatuje, že učebnica je dôležitá, pretože určuje charakter, náplň a určitý rozsah toho, čo by mal učitel’ študentov naučit'.

\section{Učebné úlohy a bloomova taxonómia}

Učebné úlohy $v$ učebniciach majú svoje nenahraditel'né miesto a vo vyučovacom procese plnia rôzne funkcie. Neslúžia len na opakovanie a precvičovanie preberanej učebnej látky, ale dobre formulovaná učebná úloha rozvíja u študentov schopnost' sebavzdelávania a sebahodnotenia (Kalhoust et al, 2002). Svec (1996) definuje „učebnú úlohu ako podnet, ktorý svojím obsahom i operačnou štruktúrou smeruje $k$ dosiahnutiu vymedzeného učebného ciela." Problematike tvorby testových úloh z rôznych oblastí chémie sa na Slovensku niekol'ko desiatok rokov venoval Silny (2000a, $2000 b, 2009)$. Na jeho práce $z$ oblasti metodiky tvorby učebných úloh nadviazala práca Ganajovej (2015). Návrhu učebných úloh z organickej chémie a biochémie sa venovali práce Jomovej (Musilova et al., 2007, Jomova et al., 2005, 2007) a z oblasti tvorby konceptuálnych úloh práce Proksu and Halakovej (2006, 2007).

Východiskom pre proces tvorby a hodnotenia učebných úloh sú taxonómie ciel’ov v kognitívnej oblasti. (Buckova, 2016). V 60. rokoch minulého storočia sa do popredia dostala Blomova taxonómia, ktorá ako prvá systematizovala vzdelávacie ciele. Práve jej šest' kategórií významne prispelo $\mathrm{k}$ problematike navrhovania a posudzovania náročnosti učebných úloh. Ďalšie taxonómie, ktoré sa objavili neskôr boli Tollingerovej taxonómia (1969), Niemierkova taxonómia (1979) a v roku 2001 sa k nim pridala revidovaná Bloomova taxonómia. Bloom si predstavoval taxonómiu ako hierarchiu, ktorá bude systematizovat' vzdelávacie ciele. Na taxonómii, ktorá 
nesie jeho meno, pracovalo zopár stoviek odborníkov a zahŕn̆ala šest' hlavných kategórií kognitívnej oblasti: Vedomost', Porozumenie, Aplikáciu, Analýzu, Syntézu a Hodnotenie (Munzenmaier and Rubin, 2013). Krietzer and Madaus (1994) pomenovali štruktúru pôvodnej taxonómie „kumulatívnou hierarchiou“: „,hierarchiou preto, lebo jednotlivé úrovne boli usporiadané podla zvyšujúcej sa komplexnosti a kumulatívnou z toho dôvodu, pretože každá nasledujúca úroveň podmieňovala osvojenie si tej predchádzajúcej“،

$\mathrm{V}$ 90. rokoch minulého storočia sa pristúpilo $\mathrm{k}$ revízii Bloomovej taxonómie z niekol'kých dôvodov:

- Po vydaní Bloomovej Príručky I sa začali ozývat' hlasy vedcov a pedagógov, ktorí upozorňovali na niektoré javy ciel'ovej roviny, ktoré nebolo možné Bloomovou taxonómiou úplne vystihnút'. Bloom ani jeho kolegovia nikdy netvrdili, že taxonómia je kompletná, ale skôr ju pokladali za štruktúru, ktorá by mohla byt' postupne upravovaná a vylepšovaná

- Od roku 1956, kedy bola Bloomova taxonómia vydaná, došlo k rozvoju kognitívnej psychológie a tým aj behaviorálnej psychológie, o ktorú sa Bloom opieral.

- Ďalším dôvodom pre revíziu bol rozpor, ktorý sa často vyskytoval pri ciel'och a úlohách. Napríklad: určité požiadavky pre kategóriu Vedomost' boli komplexnejšie ako nároky pre Analýzu alebo Hodnotenie (Bloom, 1996; Munzenmaier and Rubin, 2013).

$\mathrm{Z}$ týchto dôvodov bola pripravovaná nakladatel'stvom Longman inovácia pôvodnej Bloomovej Príručky I z roku 1956. Krátko na to sa stretla skupina odborníkov zložená z kognitívnych psychológov, teoretikov zaoberajúcich sa tvorbou kurikulí a špecialistov pre testovanie a hodnotenie. Títo pracovali na revízii 6 rokov $(1995$ - 2001) až napokon v roku 2001 bola publikovaná revidovaná Bloomova taxonómia. Jej hlavnými autormi sa stali Lorin Anderson a David Krathwohl (Hudecová, 2004). Originálna taxonómia bola jednodimenzionálna a zahrňovala 6 hierarchicky radených kategórií. Do revidovanej taxonómie však pribudla okrem dimenzie kognitívnych procesov aj druhá tzv. dimenzia poznatkov, ktorá mala 4 kategórie: faktická, konceptuálna, procedurálna, metakognitívna (Obr. 1, Hudecova, 2004). 


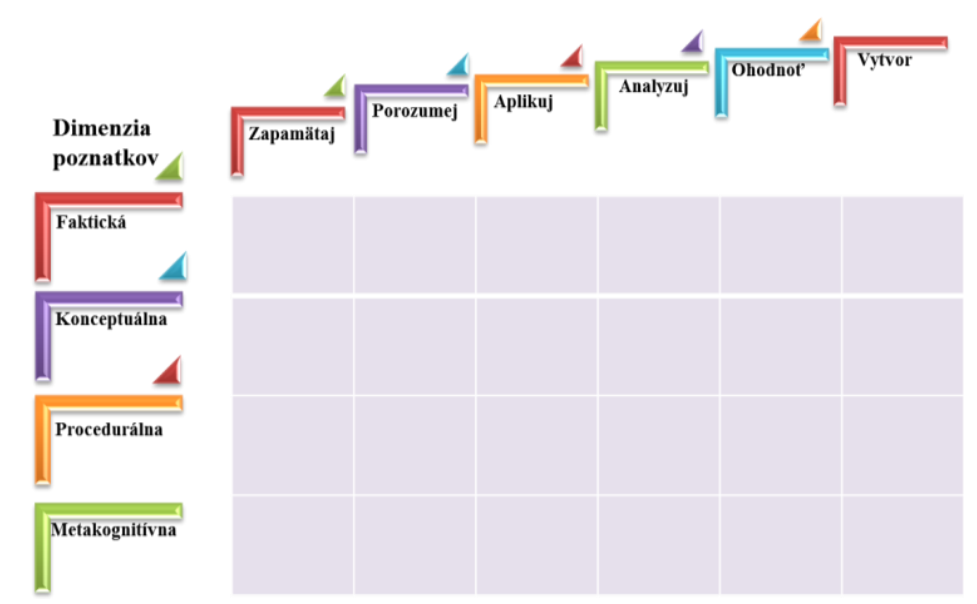

Obrázok 1 Dvojdimenzionalita revidovanej taxonómie (Wilson, 2013)

V revidovanej taxonómii sa už viac nevyskytovalo Hodnotenie na vrchole pyramídy. Namiesto toho nastúpila nová kategória - Vytvor. Kategória Vytvor bola pôvodne známa ako Syntéza. Ďalšia dôležitá zmena sa prejavila v tom, že názvy jednotlivých kategórií už viac nepredstavovali formu podstatného mena, ale nahradili ich aktívne slovesá. Výsledok revidovanej taxonómie bol taký, že už viac neopisovala správanie sa žiaka, ale jeho procesy myslenia (Obr. 2).

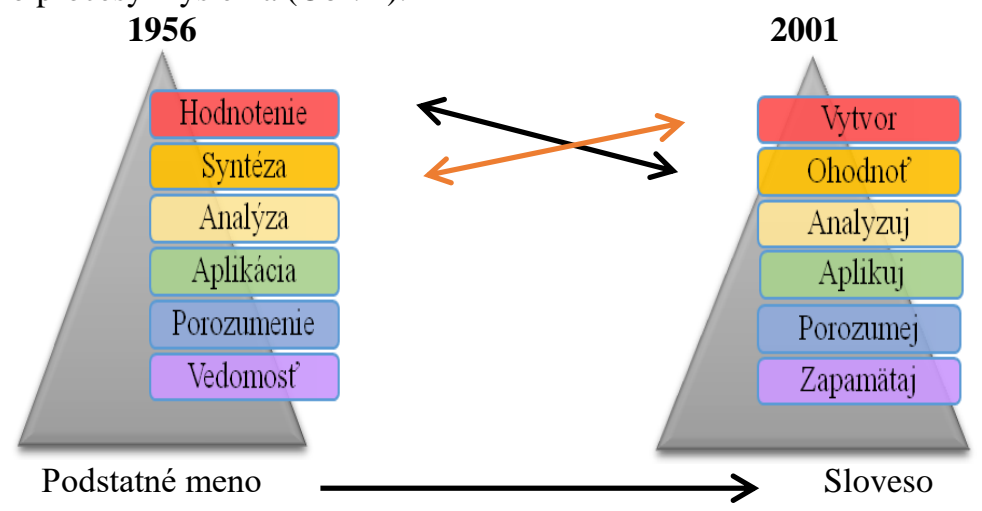

\section{Obrázok 2 Zmeny v jednotlivých kategóriách (Wilson, 2013)}

Pre analýzu učebných úloh sme sa rozhodli aplikovat' pôvodnú Bloomovu taxonómiu. Pri kategorizácii úloh sa zohl'adňovali aktívne slovesá pre jednotlivé úrovne poznávania. 


\section{Aplikácia}

Riešenie problémov na základe získaných vedomostí, faktov, techník a pravidiel.

$\begin{array}{lll}\text { Kl'účové slovesá a slová } & & \\ \text { Aplikovat' } & \text { Objavit' } & \text { Uplatnit' } \\ \text { Diskutovat' } & \text { Postavit' } & \text { Vybrat' } \\ \text { Dramatizovat' } & \text { Použit' } & \text { Vykonat' } \\ \text { Experimentovat' s } & \text { Precvičit' } & \text { Využit' } \\ \text { Identifikovat' } & \text { Predstavit' } & \text { Zorganizovat' } \\ \text { Ilustrovat' } & \text { Preložit' } & \text { Zoskupit' } \\ \text { Kategorizovat' } & \text { Spočítat' } & \text { Zreprodukovat' } \\ \text { Klasifikovat' } & \text { Spojit' } & \text { Zvolit' } \\ \text { Nájst' súvislost' } & \text { Spojit' súvisiace } & \\ \text { Naplánovat' } & \text { Spracovat' } & \\ \text { Napodobnit' } & \text { Stvárnit' } & \\ \text { Naučit' iných } & \text { Ukázat' } & \end{array}$

\section{Činnosti}

Používanie

Realizovanie

Uskutočnenie

Vykonávanie

\section{Výsledky}

Demonštrácia

Ilustrácia

Interview

Napodobnenie

Predstavenie

Prezentácia

\section{Otázky}

Aká otázky by ste kládli pri interview s...?

Aké príklady by ste uviedli na...?

Ako by ste aplikovali to, čo ste sa už naučili, aby ste získali...?

Ako by ste dokázali Vaše porozumenie...?

Ako by ste inak naplánovali...?

Ako by ste použili...?

Ako by ste riešili... s použitím toho, čo ste sa už naučili?

Ako by ste zorganizovali..., aby to poukázalo na...?

Aký by bol výsledok keby...?

Aký postup by ste použila na poukázanie...?

Ktoré poznatky by ste si zvolili, aby ste ukázali...?

Ktoré prvky by ste vybrali, aby ste zmenili...?

\section{Analýza učebných úloh vo vybraných učebniciach chémie}

$\mathrm{Na}$ analýzu učebných úloh z organickej chémie boli použité dve učebnice. V súčasnosti sa na gymnáziách pre výučbu organickej chémie využíva učebnica (Kmetova a kol., 2012), ktorú schválilo Ministerstvo školstva, vedy, výskumu a športu Slovenskej republiky v roku 2012 ako platnú učebnicu chémie. Učebnica je obsahovo rozdelená na dve časti. Prvá čast' je venovaná štruktúre a vlastnostiam anorganických látok, druhá čast' štruktúre a vlastnostiam organických látok. Druhá učebnica sa už takmer nepoužíva (Pacak a kol., 1998). Spomínané úlohy v učebniciach sme analyzovali podl'a 
štyroch kritérií: počet a usporiadanie úloh, forma zadania učebnej úlohy, obsah zamerania, kognitívna náročnost' (Tab. 2)

Tabul'ka 2 Porovnanie počtu strán a úloh v dvoch analyzovaných učebniciach chémie so zameraním na organickú chémiu

\begin{tabular}{|c|c|c|c|c|c|}
\hline \multicolumn{3}{|c|}{$\begin{array}{l}\text { Kmetova a kol., 2012: } \\
\text { Chémia pre 2. ročník gymnázia so } \\
\text { štvorročným štúdiom a } 6 \text {. ročník } \\
\text { gymnázia s osemročným štúdiom } \\
\text { Bratislava: EXPOL PEDAGOGIKA, } \\
194 \text { s. }\end{array}$} & \multicolumn{3}{|c|}{$\begin{array}{l}\text { Pacak a kol., 1998: } \\
\text { Chémia pre 2. ročník gymnázíi } \\
\text { Bratislava: SPN, } 202 \text { s. }\end{array}$} \\
\hline $\begin{array}{l}\text { Názov } \\
\text { kapitoly }\end{array}$ & $\begin{array}{l}\text { Počet } \\
\text { strán }\end{array}$ & $\mathbf{P U}$ & $\begin{array}{l}\text { Názov } \\
\text { kapitoly }\end{array}$ & $\begin{array}{l}\text { Počet } \\
\text { strán }\end{array}$ & $\mathbf{P U}$ \\
\hline $\begin{array}{l}\text { Charakteristika } \\
\text { a rozdelenie } \\
\text { organických } \\
\text { látok }\end{array}$ & 12 & 16 & $\begin{array}{l}\text { Chémia } \\
\text { zlúčenín } \\
\text { uhlíka }\end{array}$ & 19 & 16 \\
\hline Uhl'ovodíky & 21 & 25 & Uhl'ovodíky & 44 & 47 \\
\hline $\begin{array}{l}\text { Deriváty } \\
\text { uhlovodíkov }\end{array}$ & 24 & 47 & $\begin{array}{l}\text { Deriváty } \\
\text { uhl'ovodíkov }\end{array}$ & 33 & 37 \\
\hline$\Sigma$ & 57 & 88 & $\Sigma$ & 96 & 100 \\
\hline
\end{tabular}

Legenda : PU - počet úloh

\section{Počet a usporiadanie úloh vo vybraných učebniciach}

$\mathrm{Z}$ celkového počtu analyzovaných 188 sa nachádzalo 100 úloh v novšej učebnici a 88 úloh v staršej učebnici. Tematický celok Organická chémia (v staršej učebnici pod názvom - Chémia zlúčenín uhlika) bol rozdelený v oboch knihách rovnako - na tri kapitoly. Len prvá kapitola sa líšila názvom. V novšej učebnici bol názov kapitoly Charakteristika a rozdelenie organických látok, v staršej sa uviedlo označenie Chémia zlúčenín uhlika. Zvyšné dve kapitoly mali rovnaké názvy, Uhlovodiky a Deriváty uhlovodikov. Obr.3 vyjadruje porovnanie počtu úloh v oboch učebniciach.

Počet zastúpenia úloh medzi jednotlivými kapitolami bol 16:25:47 (Kmetová a kol., 2012) a 13:47:40 (Pacak a kol., 1998). Možno si všimnút' výrazný nepomer v počte úloh v druhej kapitole učebníc (Uhlovodiky) (Obr 2). V staršej učebnici je v porovnaní v novšou o $53 \%$ viac úloh zameraných na uhl'ovodíky. Jedným z dôvodov tejto odlišnosti môže byt' to, že v novšej učebnici je tejto kapitole venovaných iba 21 strán, naproti tomu Pacak a kol. (1998) v staršej knihe rozpracoval túto tému na 44 strán. 


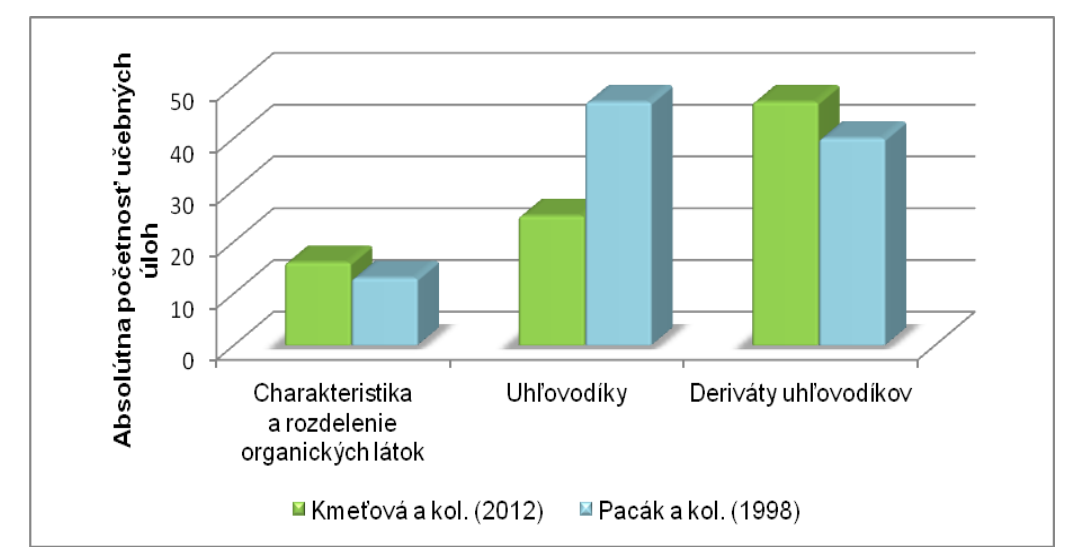

\section{Obrázok 3 Absolútna početnost’ učebných úloh vo vybraných učebniciach}

Učebné úlohy v aktuálne používanej učebnici od autorov Kmetová a kol. (2012) slúžiace $\mathrm{k}$ opakovaniu učiva sú $\mathrm{k}$ prvým dvom kapitolám (Charakteristika a rozdelenie organických látok a Uhl'ovodiky) zaradené na konci kapitol, zatial' čo pri poslednom tematickom celku „Deriváty uhl'ovodikov" sú začlenené už počas výkladového textu. Správne riešenie úlohy si môže študent overit’ na konci učebnice. V predchádzajúcej učebnici chémie od autorov Pacak a kol. (1998) je na prvý pohl'ad vidiet' rozdiel v usporiadaní učebných úloh. Pri každej téme sú na konci jednotlivých učív minimálne 3 a maximálne 10 úloh. V tejto učebnici však chýba kl'úč $\mathrm{k}$ správnemu riešeniu zadaných úloh.

\section{Forma zadania učebnej úlohy}

Pri analýze úloh v učebniciach sme sa zamerali i na kategorizáciu úloh podl'a formy zadania učebnej úlohy, teda či bola úloha zadaná písomne alebo sa od študenta požadovalo pri riešení úlohy pracovat's obrázkom, znakom, grafom alebo vzorcami zlúčenín. Proksa (2008) tieto učebné úlohy, v ktorých dominujú vizuálne prvky tiež nazýva konceptuálnymi.

Väčšina úloh v učebniciach bola zadaná slovne, učebné úlohy s vizuálnymi prvkami sa vyskytovali $\mathrm{v}$ menšej miere. V učebnici od autorov Kmetova a kol. (2012) z celkového počtu 88 úloh bolo 23 (26\%) učebných úloh $\mathrm{s}$ dominanciou vizuálnych prvkov, v učebnici od Pacaka a kol. (1998) z celkového počtu 100 úloh bolo 33 (33\%) neverbálne zadaných (Obr.4).

Učebné úlohy s prevahou vizuálnych prvkov boli väčšinou zadané vo forme chemických rovníc alebo vzorcov organických molekúl. Ani jedna učebná úloha nebola zadaná grafom, obrázkom alebo tabul'kou. 


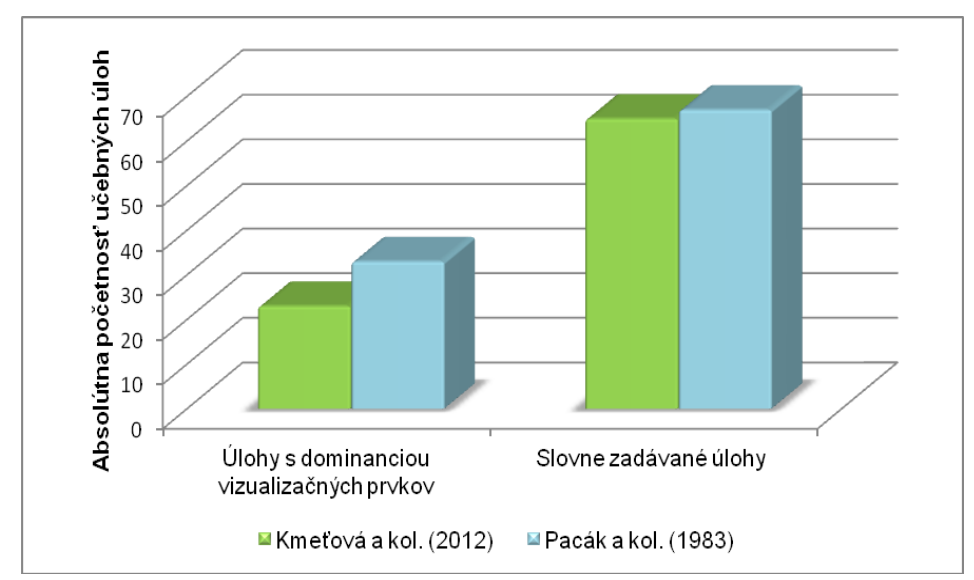

\section{Obrázok 4 Zastúpenie učebných úloh z organickej chémie podl’a formy} zadania

\section{Obsahové zameranie úloh}

Pri analýze úloh boli zadania rozdelené podla obsahu do 6 kategórii : Reakcie, Názvoslovie, Výber správneho tvrdenia, Fyzikálne a chemické vlastnosti, Zatriedenia a vymenovania a Výpočty (Tab. 3). Následne sme porovnávali obsahové zastúpenie úloh podl’a spomenutých šiestich kategórií v učebniciach od Pacaka a kol. (1998) a Kmetovej a kol. (2012).

Tabul'ka 3 Kategórie obsahového zamerania učebných úloh

\begin{tabular}{lcc}
\hline \hline & Kmetova a kol., 2012 & Pacak a kol., 1998 \\
\hline \hline Reakcie & 10 & 21 \\
Názvoslovie & 20 & 18 \\
Výber správneho tvrdenia & 38 & 19 \\
Fyzikálne a chemické vlastnosti & 3 & 11 \\
Zatriedenia a vymenovania & 15 & 24 \\
Výpočty & 2 & 7 \\
\hline \hline
\end{tabular}

\section{Kognitívna náročnost’ učebnej úlohy}

Za hlavné kritérium pre posudzovanie kognitívnej náročnosti učebných úloh sme si zvolili pôvodnú Bloomovu taxonómiu. Súbor učebných úloh $\mathrm{v}$ uvedených učebniciach bol vyhodnotení podla aktívnych slovies pôvodnej Bloomovej taxonómie. Do nižšej kategórie sme zaradili učebné úlohy zamerané na zapamätanie a riešenie problémov na základe získaných vedomostí, faktov, techník a pravidiel. Zatriedenie učebných úloh je v rozpätí kategórie I až III použitej taxonómie. Medzi učebné úlohy vyššej kognitívnej náročnosti sme začlenili otázky a zadania úloh, ktoré sa zameriavali na najvyššie kognitívne procesy podla Bloomovej taxonómie, čiže na analýzu, syntézu a hodnotenie. Z analýzy učebných úloh vyplynulo, že prevládajú úlohy, ktoré patria do skupiny nižšej kognitívnej náročnosti (Obr. 5). Približný počet zastúpenia úloh medzi jednotlivými úrovňami nižšej kognitívnej náročnosti bol 16:25:44 (Kmetova a kol., 2012) a 13:42:33 
(Pacak a kol., 1998). Z grafu je zrejmé, že väčšina učebných úloh bola na úrovni vedomostí a porozumenia, to znamená, že na tých najjednoduchších stupňoch. Z toho vyplýva, že v tematickom celku Organická chémia prevládajú učebné úlohy, ktoré patria do skupiny s najnižšou kognitívnou náročnost'ou. Učebné úlohy vyššej kognitívnej náročnosti sa vyskytovali v učebniciach v menšej miere. Približný počet zastúpenia úloh medzi jednotlivými úrovňami vyššej kognitívnej náročnosti bol 0:0:3 (Kmetova a kol., 2012) a 1:2:10 (Pacak a kol., 1998).

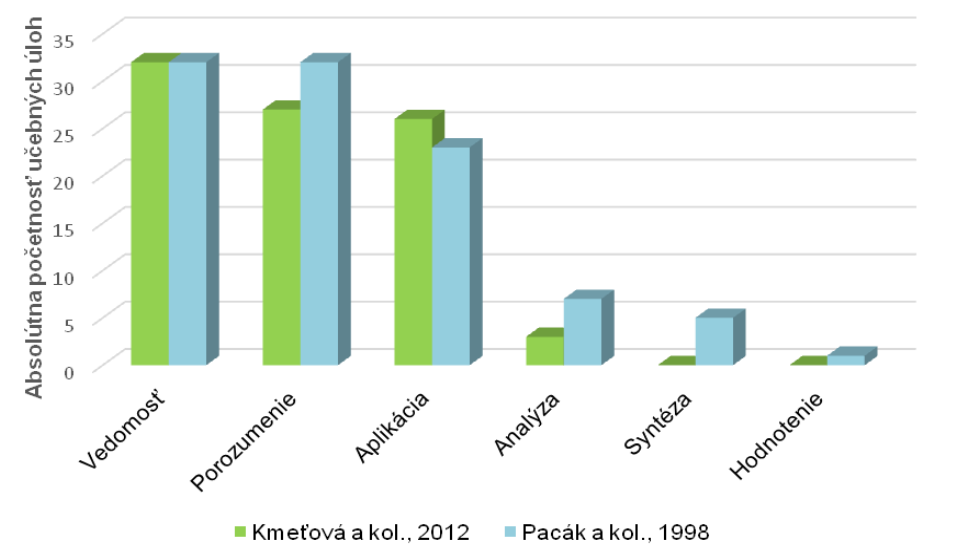

\section{Obrázok 5 Zastúpenie učebných úloh podl’a pôvodnej Bloomovej} taxonómie

Zastúpenie učebných úloh v posledných dvoch kategóriách hodnotenie a syntéza sme neočakávali, pretože na to, aby študenti mohli navrhnút' štruktúru molekuly alebo mechanizmus chemickej reakcie by mali mat' $\mathrm{v}$ teoretickej časti učebnice viac uvedených mechanizmov reakcií. Autori aktuálne používanej učebnice chémie boli nútení obsahovo a objemom sprístupňovaných informácií zohl'adňovat' pri jej tvorbe požiadavky Štátneho vzdelávacieho programu.

\section{Záver}

Úlohy a otázky $\mathrm{v}$ školských učebniciach sú jednou z oblastí, ktorú je potrebné analyzovat' ak chceme nájst' cestu, ako podporit' u študentov ciel'avedomé učenie. Učebné úlohy by nemali byt' limitované z hl'adiska svojej náročnosti len na proces zapamätania si faktov, ale mali by vyvolat' zložitejšie myšlienkové operácie, ktoré pomáhajú študentom poznatky aplikovat', analyzovat' a dávat' do vzájomných vzt'ahov. Pedagógovia, ktorí pripravujú študentov pre d'alšie štúdium chémie, by mali pre svojich študentov okrem učebných úloh uvedených $\mathrm{v}$ učebniciach používat' i iné študijné podklady, v ktorých sú uvedené učebné úlohy s vyššou kognitívnou náročnost'ou.

\section{Bibliographic references}

AHTINEVA, A. 2005. Textbook analysis in the service of chemistry teaching. In Universitas Scientiarum. vol. 10, pp. 25-33. 
BLOOM, B. 1996. Reflections on the Development and the Use of the Taxonomy. In Anderson, L., Sosniak, L. Bloom's Taxonomy: A Forty-Year Retrospective. In The National Society for the Study of Education. s. 1- 8.

BUCKOVA, K. - HALAKOVA, Z. - NAGYOVA, S. 2016. Porovnanie a analyza ucebnych uloh vo vybranych ucebniciach biologie. In Biologia, ekologia, chemia, vol. 20, no. 4, pp.33-37. ISSN 1338 - 1024.

GANAJOVA, M. 2015. Metodika tvorby ucebnych uloh a didaktickych testov pre chemiu. Kosice: Univerzita Pavla Jozefa Safarika. [cit. 2016-1109]. Available online: http://unibook.upjs.sk/image/data/ knihy\%202015/PF/Metodika-tvorby-ucebnych-uloh-a-didaktickych-testovpre-chemiu-Ganajova.pdf

GARINGER, D. 2001. Textbook selection for the ESL classroom. In Eductional Resources Information center DIGEST. [cit. 2016-09-11]. Available online: http://www.cal.org/resources/Digest/0210garinger.html

HALAKOVA, Z. - PROKSA, M. 2006. Vizualna gramotnost a riesenie ucebnych uloh z chemie. In Chemicke listy, vol. 100, no. 3, pp. 213 -219.

HALAKOVA, Z. - PROKSA, M. 2007. Two kinds of conceptual problems in chemistry teaching. In Journal of Chemical Education, vol. 84, no.1, pp. 172 -174.

HUDECOVA, D. 2004. Revize Bloomovy taxonomie edukacnich cilu. In Pedagogika.vol. 54, pp. $274-283$.

JOMOVA, K. a kol. 2005. Vizualizacia vybranych chemickych experimentov pre stredne skoly : Organicka chemia a biochemia : vysokoskolske ucebne texty. Nitra : UKF. 120s. ISBN 80-8050-931- X.

JOMOVA, K. a kol. 2007. Tema nukleove kyseliny v riesenych ulohach. In Aktualne trendy vo vyucovani prirodovednych predmetov. Bratislava: UK. s 55-258. ISBN 978-80-88707-90-5.

KALHOUS, Z. a kol. 2002. Skolni didaktika. Praha : Portal. 448 s. ISBN 807178-253-X

KMETOVA, J. a kol. 2012. Chemia pre 2. rocnik gymnazia so stvorrocnym studiom a 6. rocnik gymnazia s osemrocnym studiom. Bratislava : EXPOL PEDAGOGIKA. 184 s. ISBN $978-80-8091-271-0$.

KREITZER, A. - MADAUS, A. 1994. Emprical Investigations of the Hierarchical Structure of the Taxonomy. In Anderson, L. and Sosniak, L. Bloom's Taxonomy: A Forty-Year Retrospective. Chicago: The National Society for the Study of Education. pp. $64-81$.

LIU, Y. 2016. Content Analysis of The Diagrammatic Representations of Primary Science Textbooks. In Eurasia Journal of Mathematics, Science \& Technology Education. vol. 12, no. 8, pp. 1937-1951.

MARTIN, M. O. - MULLIS, I. V. S. - FOY, P. 2008. TIMSS 2007 International Science Report. Boston TIMSS \& PIRLS International Study Center. 512 s. ISBN: 1-889938-49-1.

McGRATH, I. 2006. Teachers' and learners' images for coursebooks. In ELT Journal. vol. 60, no. 2, pp. $171-180$.

MUSILOVA, J. a kol, 2007. Riesene ulohy so zameranim na lipidy. In Aktualne trendy vo vyucovani prirodovednych predmetov. Bratislava : Univerzita Komenskeho. s. 259 - 262. ISBN 978-80-88707-90-5. 
MUNZENMAIER, C. - RUBIN, N. 2013. Perspectives Boom's Taxonomy: What's old is a new again. [cit. 2017-08-09]. Available online: http://onlineteachered.mit.edu/edc-pakistan/files/best-practices/session-2/PreSession-Munzenmaier-Rubin-2013.pdf

PACAK, J. a kol. 1998. Chemia pre 2. Rocnik gymnazii. Praha : SPN. 202 s. ISBN $80-08-02860-2$.

PROKSA et al., 2008. Metodologia pedagogickeho vyskumu a jeho aplikacia $\mathrm{v}$ didaktikach prirodnych vied. Bratislava : Univerzita Komenskeho v Bratislave. 229 s. ISBN 978-80-223-2562-2.

SILNY, P. - KMETOVA, J. 2009. Otazky a ulohy z chemie pre 9. rocnik zakladnych skol.. Zvolen : Bratia Sabovci. 86 s. ISBN 978-80-89241-29-3.

SILNY, P. - KUCHAROVA, D. 2000a. Ulohy $\mathrm{z}$ chemie pre 8. rocnik zakladnych skol.. Bratislava: EXPOL PEDAGOGIKA. 90 s. ISBN 80-89003-05-2.

SILNY, P. - ZVERENCOVA, K. 2000b. Ulohy a modely usmernovania riesenia uloh $\mathrm{z}$ organickej chemie. Zvolen : Bratia Sabovci. 164 s. ISBN 978-80-89241-14-9.

SVEC, V. a kol. 1996. Praktikum didaktickych dovednosti. Brno : MU. 90 s. ISBN 80-210-1365-6.

TOMLINSON, B. et al. 2001. ELT courses for adults. In ELT Journal. vol. 55 , no. 1 , pp. $80-101$.

WILSON, O. 2013. Anderson and Krathwohl Understanding the New version of Bloom's Taxonomy. [cit. 2017-01-12]. Available online: https://thesecondprinciple.com/teaching-essentials/beyond-bloom-cognitivetaxonomy-revised/

doc. RNDr. Zita Jenisová, PhD.

Univerzita Konštantína Filozofa v Nitre

Fakulta prírodných vied, Katedra chémie,

Tr. A. Hlinku 1, 94901 Nitra

Slovakia

zjenisova@ukf.sk 